\title{
Article \\ Mercury Bioaccumulation in Benthic Invertebrates: From Riverine Sediments to Higher Trophic Levels
}

\author{
Laura Marziali * (D), Claudio Roscioli (D) and Lucia Valsecchi \\ CNR-IRSA Water Research Institute, National Research Council, Via del Mulino 19, 20861 Brugherio, MB, Italy; \\ claudio.roscioli@irsa.cnr.it (C.R.); lucia.valsecchi@irsa.cnr.it (L.V.) \\ * Correspondence: laura.marziali@irsa.cnr.it; Tel.: +39-039-21694207
}

Citation: Marziali, L.; Roscioli, C.;

Valsecchi, L. Mercury

Bioaccumulation in Benthic

Invertebrates: From Riverine

Sediments to Higher Trophic Levels.

Toxics 2021, 9, 197. https://doi.org/

$10.3390 /$ toxics 9090197

Academic Editors: Víctor

Manuel León and Zunyao Wang

Received: 2 July 2021

Accepted: 20 August 2021

Published: 24 August 2021

Publisher's Note: MDPI stays neutral with regard to jurisdictional claims in published maps and institutional affiliations.

\begin{abstract}
Riverine sediments are important sites of mercury methylation and benthic invertebrates may be indicators of $\mathrm{Hg}$ exposure to higher organisms. From 2014 to 2018, sediments and invertebrates were collected along a mercury gradient in the Toce River (Northern Italy) and analyzed for $\mathrm{THg}$ and $\mathrm{MeHg}$. Concentrations in invertebrates, separated according to taxon and to Functional Feeding Group, ranged from 20 to $253 \mu \mathrm{g} \mathrm{kg}{ }^{-1}$ dry weight (d.w.) for $\mathrm{THg}$, increasing from grazers (Leuctra, Baetis, Serratella) to predators (Perla). MeHg ranged from 3 to $88 \mu \mathrm{g} \mathrm{kg}^{-1} \mathrm{~d}$.w. in biota, representing $6-53 \%$ of $\mathrm{THg}$, while in sediments it was mostly below $\mathrm{LOD}\left(0.7 \mu \mathrm{g} \mathrm{kg}^{-1}\right)$, accounting for $\leq 3.8 \%$ of $\mathrm{THg}$. The Biota-Sediment Accumulation Factor (BSAF, ranging 0.2-4.6) showed an inverse relation to exposure concentrations ( $\mathrm{THg}$ in sediments, ranging $0.014-0.403 \mu \mathrm{g} \mathrm{kg}{ }^{-1} \mathrm{~d} . \mathrm{w}$.) and to organic carbon. THg in invertebrates (up to $73 \mu \mathrm{g} \mathrm{kg}{ }^{-1}$ wet weight), i.e., at the basal levels of the aquatic trophic chain, exceeded the European Environmental Quality Standard for biota (20 $\mu \mathrm{g} \mathrm{kg}{ }^{-1}$ w.w.), posing potential risks for top predators. Concentrations in adult insects were close to those in aquatic stages, proving active mercury transfer even to terrestrial food chains.
\end{abstract}

Keywords: methylmercury; aquatic insects; freshwater sediments; bioaccumulation

\section{Introduction}

Freshwater sediments are an essential reservoir where mercury accumulates, deriving from atmospheric deposition, terrestrial runoff, and local contamination sources [1-3]. Sediments can be important sites for methylation, which is favored under anaerobic conditions by the presence of sulphate- or iron-reducing bacteria at the water-sediment interface $[4,5]$. Methylmercury $(\mathrm{MeHg})$ is the most toxic mercury compound, exerting neurotoxic effects, and it is easily released by sediments and bioaccumulated in food webs $[2,6,7]$. Moreover, $\mathrm{MeHg}$ shows a strong biomagnification potential, significantly increasing both as concentration and as a percentage to total mercury ( $\mathrm{THg}$ ) with increasing trophic level, posing the risk of secondary poisoning to top predators [8-10].

Mercury transfer from abiotic compartments (water, sediment) to biota is strongly influenced by site-specific physical and chemical factors, such as $\mathrm{pH}$, redox conditions, presence of ligands, temperature, etc., which play an important role in $\mathrm{Hg}$ bioavailability $[5,11,12]$. In riverine ecosystems, these parameters may show large variations and the study of mercury cycling may become rather challenging. Mercury contamination is of high concern in freshwater ecosystems. In Europe, more than 45,000 water bodies fail to achieve the "good chemical status" according to Water Framework Directive because mercury concentrations exceed the Environmental Quality Standard (EQS) for water or, mostly, the EQS for biota (generally estimated on fish tissues) [13-15]. As well as this, fish consumption in more than $35 \%$ of US freshwaters is limited because of elevated $\mathrm{MeHg}$ values, even where no point sources of mercury are present [2].

Benthic invertebrates live in close proximity to sediments; thus, they are directly exposed to sediment contamination. These organisms are key vectors of mercury contamination from abiotic compartments to trophic chains [7]. They serve as food for many 
fish species in the aquatic habitat, while adult insects are also prey for terrestrial animals such as insects, birds, and bats [16]. However, studies on mercury bioaccumulation in freshwater invertebrates are limited (e.g., [10,11,17-19]). Aquatic invertebrates can be characterized by relevant concentrations of $\mathrm{MeHg}$, mostly ranging between $10 \%$ and $90 \%$ of $\mathrm{THg}$, determining significant transfer to predators $[10,20]$. Thus, they are important sentinels for mercury exposure for a wide range of higher organisms.

There is little information about the uptake routes and mechanisms responsible for mercury bioaccumulation in invertebrates [21,22]. However, it is widely accepted that diet is the dominant exposure pathway for mercury for most animals [2,12]. Aquatic insects belong to all categories of consumers, from herbivorous to predators, thus different Functional Feeding Groups (FFGs) may be characterized by different mercury concentrations and biomagnification within invertebrate communities may also occur $[10,18]$. Moreover, other determinants, such as specific physiological mechanisms, may influence the bioaccumulation potential of $\mathrm{Hg}$ [23]. For example, Cid et al. [16] found at the same site mercury concentrations in the mayfly Ephoron virgo two-fold higher in comparison to the caddisfly Hydropsyche exocellata, even if both are considered filter feeders. Moreover, the same authors highlighted that $\mathrm{Hg}$ concentrations in aquatic insects also change with size and life cycle stages. Notably, some works reported similar mercury values in aquatic and adult stages of freshwater insects, proving the efficient transfer of the contaminant to terrestrial ecosystems and to higher trophic levels [16,24-26].

Our aim was to investigate $\mathrm{THg}$ and $\mathrm{MeHg}$ concentrations in different invertebrate taxa collected in the Toce River (Northern Italy), characterized by a legacy mercury contamination deriving from a chlor-alkali plant. Organisms were grouped in different FFGs to test potential differences bound to trophic resources. The relation between bioaccumulation and sediment contamination, considered as primary mercury storage in the ecosystem, was analyzed. THg bioaccumulation in different life stages (pre-imaginal stages, exuviae, and adults) of some taxa was compared, to analyze the efficiency of mercury cycling in the environment of these organisms.

\section{Materials and Methods}

\subsection{Study Area}

The Toce River flows in the Ossola Valley, Central-Western Alps, Piedmont Region, Northern Italy. The river is $84 \mathrm{~km}$ long and is one of the main tributaries of Lake Maggiore, flowing into the Pallanza Basin with an average annual flow of $62 \mathrm{~m}^{3} \mathrm{~s}^{-1}$ (Figure 1). A mercury-cell chlor-alkali plant is located about $20 \mathrm{~km}$ upstream from the river mouth, in Pieve Vergonte town (VB), and it was definitively closed at the end of 2017. In the last century, until 1996, wastewaters were discharged directly into the Toce River, where mercury was proved to accumulate in sediments and biota. Peak concentrations of $\mathrm{THg}$ in sediments in the Pallanza Basin reached values up to $26 \mathrm{mg} \mathrm{kg}^{-1}$ dry weight (d.w.) in the 1940s, as estimated from the analysis of $\mathrm{Hg}$ vertical profiles in sediment cores sampled in the Pallanza Basin [27-29]. Mercury concentrations in the river sediments are constantly monitored by the International Commission for the Protection of the ItalianSwiss Waters (CIPAIS; www.cipais.org (accessed on 19 May 2021). Values downstream of the chlor-alkali plant are generally below or in line with the consensus-based Threshold Effect Concentration of $0.18 \mathrm{mg} \mathrm{kg}^{-1}$ d.w. (cb-TEC), i.e., the concentration below with toxic effects for benthic invertebrates are not expected [30], showing a mean value of $0.18 \pm 0.20 \mathrm{mg} \mathrm{kg}^{-1}$ d.w. at the river mouth between 2008 and 2018 [29]. However, preliminary data on bioaccumulation in benthic invertebrates proved that $\mathrm{THg}$ values are generally above the European EQS for biota of $20 \mu \mathrm{g} \mathrm{kg}{ }^{-1}$ wet weight (w.w.), showing the bioavailability of the contaminant and posing a potential risk of secondary poisoning to higher trophic levels [26,31]. Up to date, mercury concentrations in the river water are below the European EQS of $70 \mathrm{ng} \mathrm{L}^{-1}$ as a maximum allowable concentration [31]. 


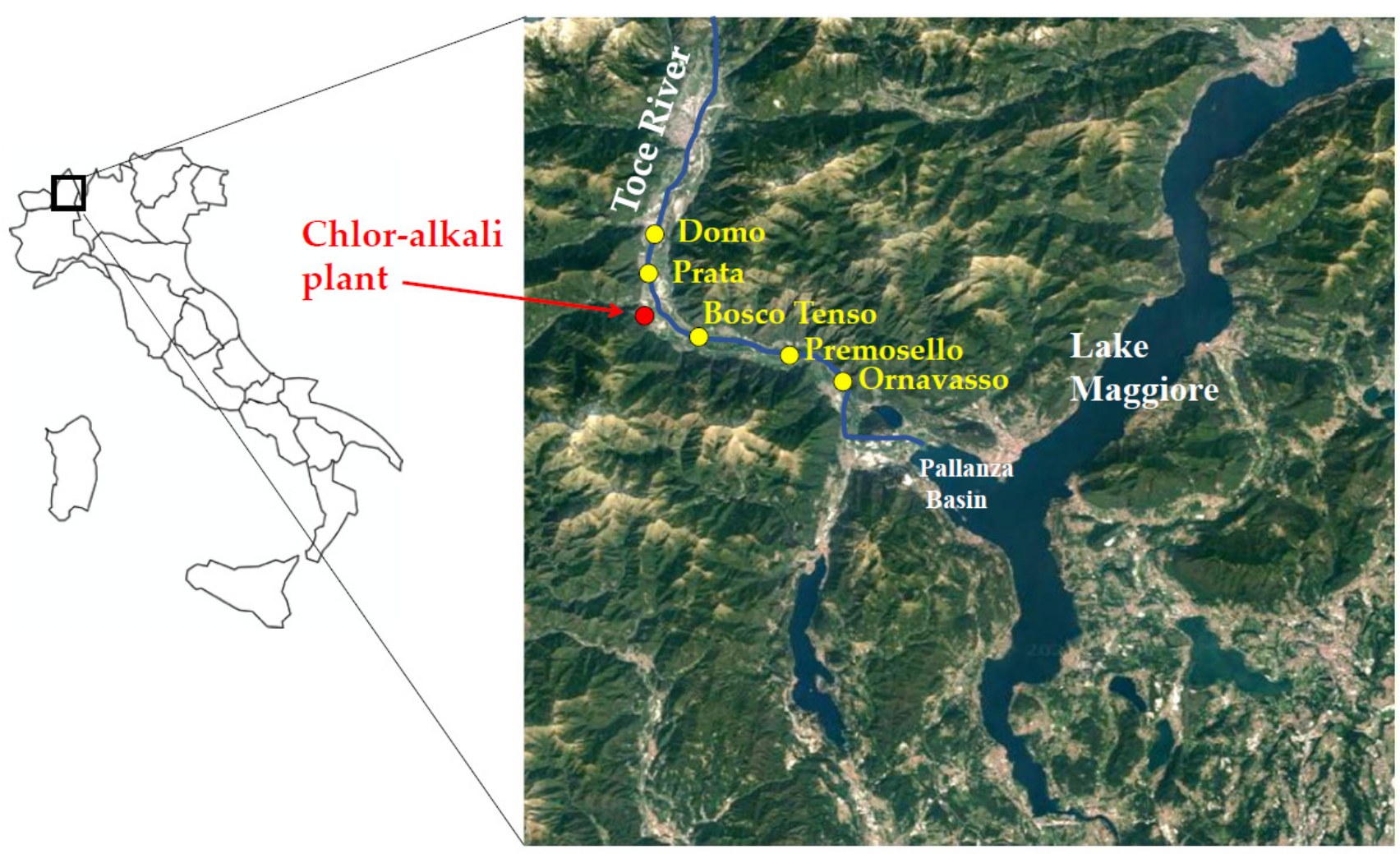

Figure 1. Map of the study area. Sampling points and the location of the chlor-alkali plant along the Toce River (Piedmont Region, Northern Italy) are reported.

Five sampling sites were selected along the $30 \mathrm{~km}$-long final stretch of the Toce River (Figure 1): Domo and Prata are located 8.6 and $3.4 \mathrm{~km}$ upstream of the chlor-alkali plant, respectively, while Bosco Tenso, Premosello, and Ornavasso are located downstream the industrial area, at 3.7, 8.7 and $13.1 \mathrm{~km}$ downstream, respectively. This river stretch is relatively uniform for hydromorphological characters and hosts species-rich benthic communities both upstream and downstream of the industrial site [32]. The width of the riverbed is $40-60 \mathrm{~m}$ and the maximum depth is more than $1.5 \mathrm{~m}$. In pool areas, predominant substrates are sand and gravel [32]. A few data on $\mathrm{THg}$ concentrations in porewater and at the water-sediment interface were derived in 2014-2015 using Diffusive Gradients in Thin films passive samplers $[26,31]$ and resulted comprised between 3 and $56 \mathrm{ng} \mathrm{L}^{-1}$, with an increasing trend from Domo to Ornavasso.

\subsection{Sediment and Benthic Invertebrate Sampling}

At each sampling station, benthic invertebrates and sediments were collected in 2014, 2016, 2017, and 2018 in April and October, i.e., in two periods of intense emergence for aquatic insects and of intermediate discharge values of the nival-glacial flow regime.

Benthic organisms were extensively sampled using hand nets in the depositional areas of each site (i.e., in the pools, characterized by the maximum accumulation of the finest fractions of sediments such as silt and clay, where contaminants are mainly adsorbed), to collect appropriate biomass for chemical analysis. Invertebrate drift was limited to some small-sized individuals, as we observed using drift nets positioned during the samplings, thus we supposed that our samples were representative of the site. Benthic organisms were separated on-site in taxonomic groups (generally family) and were left in the river water for at least four hours to allow gut purging. Organisms of similar size were selected. Then they were sieved, gently dried with absorbent paper, and frozen at $-18{ }^{\circ} \mathrm{C}$ in a portable freezer. In the laboratory, whole bodies were freeze-dried $\left(72 \mathrm{~h}\right.$ at $0.1 \mathrm{mbar}$ and $-45^{\circ} \mathrm{C}$; Telstar 
LyoQuest), homogenized with a ball mill (Retsch MM2000, Retsch Technology GmbH, Haan, Germany), and preserved in dark-glass bottles until mercury analysis.

Some specimens were preserved in $70 \%$ ethanolic solution and used for a more precise taxonomic identification under a stereomicroscope using identification keys [33-36]. The full list of taxa considered for chemical analysis is reported in Table 1. The most abundant taxa, which were generally present in all samples, were: Crustacea Gammaridae Echinogammarus, Diptera Tipulidae, Tabanidae, and Limoniidae, Ephemeroptera Heptageniidae Ecdyonurus, and Ephemeroptera Baetidae Baetis. The other taxa were not always present with sufficient biomass to carry out chemical analysis. The occurrence of each taxon at each site is reported in Figure S1 (Supplementary Material). The number of individuals per taxon per each sample ranged from 5 for Perla to over 200 individuals for Baetis, depending on the size and abundance of the organisms collected. A minimum of $0.05 \mathrm{~g} \mathrm{~d}$.w. was necessary for $\mathrm{THg}$ analysis. However, for the four dominant taxa, a minimum of $0.5 \mathrm{~g}$ d.w. was generally collected.

Occasionally, it was possible to collect different life stages of the same taxon at the same site and sampling date. Pupae (about 10 individuals) were sorted from hand-net samples. Pupal exuviae (minimum 100 individuals) were collected directly from the surface of river boulders (e.g., Rhyacophilidae) or using drift nets (e.g., Heptageniidae). Adults (minimum 10 individuals) were picked with tweezers directly from the water surface. All were frozen, freeze-dried, and homogenized, as described above.

For sediments, at each site, different sub-samples were collected in the pool areas with a stainless-steel spoon and mixed in order to obtain a $2 \mathrm{~L}$ representative sample. Sediments were preserved in acid-washed dark-glass bottles at $4{ }^{\circ} \mathrm{C}$ until freeze-drying $(72 \mathrm{~h}$ at $0.1 \mathrm{mbar}$ and $\left.-45^{\circ} \mathrm{C}\right)$. Sediments were sieved to separate the finest fraction $(<63 \mu \mathrm{m}$ grain size), which was preserved in dark-glass bottles and used for mercury analysis. Contaminants are frequently associated with the fine fraction of aquatic sediments [37], thus analysis of the $<63 \mu \mathrm{m}$ fraction is the most widespread in monitoring to reduce the variability between samples due to grain size composition [38]. Moreover, only the finest sediments can be ingested by small-sized invertebrate taxa (e.g., [39]).

Table 1. Invertebrate taxa collected during the study, taxonomic identification, main feeding habits (in brackets, secondary feeding habits are reported) according to literature [40] and Functional Feeding Groups (FFG) used to group the organisms for statistical analysis.

\begin{tabular}{|c|c|c|c|c|}
\hline Order & Family & Genus/Species & Feeding Habits & FFG \\
\hline Ephemeroptera & Ephemerellidae & Serratella ignita & grazer/gatherer & \multirow{3}{*}{ grazers } \\
\hline Ephemeroptera & Baetidae & $\begin{array}{l}\text { Baetis rhodani }+ \text { Baetis } \\
\text { alpinus/lutheri gr. }\end{array}$ & grazer/gatherer & \\
\hline Plecoptera & Leuctridae & Leuctra sp. & grazer/gatherer/shredder & \\
\hline Ephemeroptera & Heptageniidae & Ecdyonurus venosus & grazer/gatherer/omnivore ${ }^{a}$ & \multirow{5}{*}{ gatherers-predators } \\
\hline Plecoptera & Perlodidae & Dictyogenus + Isoperla & predator (grazer/gatherer/shredder) & \\
\hline Diptera & Limoniidae & Hexatoma sp. & predator (shredder) & \\
\hline Diptera & Tipulidae ${ }^{b}$ & Tipula lateralis & gatherer (shredder) & \\
\hline Diptera & Tabanidae $^{b}$ & Chrysops sp. + Haematopota sp. & predator (gatherer) & \\
\hline Trichoptera & Limnephilidae $^{b}$ & Allogamus sp. & shredder (grazer/predator) & \multirow{2}{*}{ shredders } \\
\hline Amphipoda & Gammaridae & Echinogammarus sp. & shredder & \\
\hline Ephemeroptera & Ephemeridae & Ephemera danica & active filter feeder (gatherer) & active filter feeders \\
\hline Oligochaeta & Lumbricidae & Eisenia tetraedra & gatherer & gatherers \\
\hline Trichoptera & Rhyacophilidae & Rhyacophila sp. & predator & small sized predators \\
\hline Plecoptera & Perlidae & Perla sp. & predator (grazer) & large sized predators \\
\hline
\end{tabular}

${ }^{a}$ according to literature, Heptageniidae show a tendency toward omnivory [41]. ${ }^{\mathrm{b}}$ the feeding habits of Diptera were derived from [34]. 


\section{3. $\mathrm{THg}$ and $\mathrm{MeHg}$ Analysis}

Total concentrations of mercury in organisms (analyzed in aliquots of $0.025 \mathrm{~g}$ d.w. of whole bodies) and sediments (in aliquots of $0.1 \mathrm{~g}$ d.w. of $<63 \mu \mathrm{m}$ grain size fraction) were determined by thermal decomposition, amalgamation, and atomic absorption spectrometry according to the US-EPA 7473 method [42] using an Automated Mercury Analyzer (AMA-254, FKV srl, Bergamo, Italy). The instrument sensitivity is $0.01 \mathrm{ng} \mathrm{Hg}$, so the LOD calculated considering a sample weight of $0.025 \mathrm{~g}$ is $0.4 \mu \mathrm{g} \mathrm{Hg} \mathrm{kg}^{-1}$. The Limit of Quantification (LOQ), calculated as ten times the standard deviation of the blank and considering the sample mass of $0.025 \mathrm{~g}$, is $0.009 \mathrm{mg} \mathrm{kg}^{-1}$. The absolute instrument working range is 0.05 to $600 \mathrm{ng} \mathrm{Hg}$.

For quality assurance, the certified reference materials BCR-CRM278 Mussel tissue (certified value $=0.196 \pm 0.007 \mathrm{mg} \mathrm{kg}^{-1}$ ) and BCR-CRM320R Channel sediment powder (certified value $=0.85 \pm 0.09 \mathrm{mg} \mathrm{kg}^{-1}$ ) of the Institute for Reference Materials and Measurements (IRRM, Geel, Belgium) were analyzed. Mean recovery was $105 \pm 3.6 \%(\mathrm{n}=27)$ and $99 \pm 1.5 \%(\mathrm{n}=16)$, respectively. Analyses were run in triplicate for sediments and in duplicate or triplicate for organism tissues, according to availability of biomass. The coefficient of variation was $\leq 5 \%$.

$\mathrm{MeHg}$ was analyzed in five taxa (Echinogammarus, Diptera, Ecdyonurus, Baetis, and Trichoptera Limnephilidae) and in sediments collected at the five sites in April 2017. The analysis was performed by static headspace and GC-MS acquisition, whereas quantification was carried out using stable isotope dilution analysis. First, $0.25 \mathrm{~g}$ d.w. of homogenized tissue or $0.5 \mathrm{~g}$ d.w. of sediments were spiked with a $1 \mathrm{~mL}$ of ${ }^{201} \mathrm{Hg}$ enriched solution diluted 1:100 ( ${ }^{201} \mathrm{Hg}, 5.49 \pm 0.04 \mu \mathrm{g} \mathrm{g}^{-1}, 96.5 \%$, ISC Science, Oviedo, Asturias, Spain). Then, they were microwave digested at $70{ }^{\circ} \mathrm{C}$ for $3 \mathrm{~min}$ adding $3 \mathrm{~mL}$ of $\mathrm{HCl}$. Acid extracts were filtered (CA $0.4 \mu \mathrm{m}$ ) and brought to a $\mathrm{pH}$ of 5.5 adding $10 \mathrm{~mL}$ of buffer solution (sodium acetate/acetic acid $1 \mathrm{M}$ ) and $3 \mathrm{~mL}$ of $1 \mathrm{M} \mathrm{KOH}$. MeHg ethylation was obtained by mixing each sample with $1 \mathrm{~mL}$ of $\mathrm{NaBEt}_{4} 1 \%$ in HPLC grade water (sodium tetraethylborate, 97\%) directly in the pH-adjusted extract. GC-MS analysis was carried out using Thermo Fisher GC-MS system (respectively Focus GC and DSQ ${ }^{\mathrm{TM}}$ II single quadrupole) equipped with TriPlus $\mathrm{RSH}^{\mathrm{TM}}$ autosampler (Thermo Fisher Scientific, Rodano, Milan, Italy), able to static headspace technique. The samples were incubated for $12 \mathrm{~min}$ at $90{ }^{\circ} \mathrm{C}$ and $1.2 \mathrm{~mL}$ of the headspace was injected in the GC-MS. Ions considered for quantification were $\mathrm{MeHg} 215+244 \mathrm{~m} / \mathrm{z}$ and $\mathrm{Me}^{201} \mathrm{Hg} 216+245 \mathrm{~m} / \mathrm{z}$. A stock standard solution was prepared by dissolving methylmercury chloride salt in a solution made with methanol and hydrochloric acid $18 \%$ with a proportion of $30 / 70 \% v / v$. This solution was used to build a six-point calibration curve (0.03-2 $\mu \mathrm{g} \mathrm{MeHg})$. Cross contribution signal due to isotope pattern of native $\mathrm{Hg}$ and internal standard was corrected by software (Xcalibur 1.4). For quality assurance, the certified reference materials SRM-2974a Mytilus edulis tissue (National Institute of Standards and Technologies-NIST, Gaithersburg, MD, USA; reference value $=69.06 \pm 0.81 \mu \mathrm{g} \mathrm{kg}^{-1}$ ) and ERM-CC580 estuarine sediment (IRMM, Geel, Belgium; reference value $\left.=75 \pm 4 \mu \mathrm{g} \mathrm{kg}^{-1}\right)$ were analyzed. Recoveries were $102.5 \pm 6.8 \%(\mathrm{n}=6)$ and $94.5 \pm 8.8 \%(\mathrm{n}=6)$, respectively. The LOD of the method is $0.7 \mu \mathrm{g} \mathrm{kg}^{-1}$.

Organic carbon content (OC) in sediments was determined in $0.5 \mathrm{~g}$ d.w. samples by back-titration after oxidation with potassium dichromate in the presence of sulphuric acid, following the Walkley-Black procedure [43]. The LOD of the method is $0.14 \%$ OC, the LOQ is $0.46 \%$ OC, calculated as 3.3 times the LOD value [44]. The coefficient of variation for triplicate analysis was $<5 \%$.

\subsection{Data Analysis}

Each taxon was assigned to a Functional Feeding Group according to ecological information stored in the freshwaterecology.info database [40]. For Diptera, the feeding habit of each taxon was derived from [34]. 
To evaluate the bioavailability of mercury in sediments, the Biota-Sediment Accumulation Factor (BSAF, adimensional) was calculated according to the following formula [45]:

$$
B S A F=\frac{C_{\text {org }}}{C_{\text {sed }}}
$$

where $C_{\text {org }}$ is the tissue concentration ( $\mathrm{mg} \mathrm{kg}^{-1}$ d.w.), $C_{\text {sed }}$ is $\mathrm{Hg}$ concentration in sediments (mg kg-1 d.w.).

Pearson's correlation coefficient was calculated between variables: concentrations of $\mathrm{THg}$ or $\mathrm{MeHg}$ in organisms and sediments, $\mathrm{OC}$, and percent fine sediments (i.e., $<63 \mu \mathrm{m}$ grain size).

One-way Analysis of Variance (ANOVA) followed by Tukey's post-hoc test was carried out to test differences of $\mathrm{THg}$ or MeHg concentrations among sites, taxa, or FFGs. KruskallWallis ANOVA followed by Dunn's post-hoc test was carried out to test differences of $\mathrm{MeHg}$ concentrations among taxa or FFGs. T-test was used to test differences of THg and $\mathrm{MeHg}$ concentrations between sampling seasons (April vs. October).

Comparison between $\mathrm{THg}$ concentrations in different life stages was carried out with a $t$-test for dependent samples.

Prior to the previous analyses, the normality of data was tested with the KolmogorovSmirnov test and homogeneity of variance with Levene's test. In the case of deviances, $\log _{10}(\mathrm{x})$ transformation was carried out.

All analyses were run with Statistica 8.0 (StatSoft Inc., Tulsa, OK, USA) and Past 4.05 [46] software.

\section{Results and Discussion}

\subsection{THg in Sediments and Biota}

Total mercury concentrations in sediments at the most upstream site Domo (mean $0.036 \pm 0.023 \mathrm{mg} \mathrm{kg}^{-1} \mathrm{~d}$.w.) were in line with the background value of $0.044 \pm 0.026 \mathrm{mg} \mathrm{kg}^{-1} \mathrm{~d}$.w. estimated for the Toce River [32], while concentrations at the sites downstream of the industrial area (Bosco Tenso, Premosello, and Ornavasso) significantly exceeded the basal level, with a mean of $0.096 \pm 0.075 \mathrm{mg} \mathrm{kg}^{-1}$ d.w. (ANOVA, $p<0.05$ in comparison to Domo) (Figure S1). Sediments at Prata, which is located about $3 \mathrm{~km}$ upstream of the chlor-alkali plant, showed a slight mercury enrichment, with a mean of $0.055 \pm 0.033 \mathrm{mg} \mathrm{kg}^{-1}$ d.w., and concentrations did not differ significantly from those of both Domo and the downstream sites (ANOVA, $p>0.05$ for post-hoc comparisons), probably due to past atmospheric transport of the contaminant from the industrial area [32].

$\mathrm{THg}$ concentrations in sediments were positively correlated to $\mathrm{OC}(\mathrm{r}=0.66, p<0.05)$. This relation is reported also in other case studies (e.g., [5,12]) and confirms the high affinity between $\mathrm{Hg}$ and organic matter, which is a strong ligand for this metal due to the strong binding affinity between $\mathrm{Hg}$ and thiol (-SH) groups [1,12,47].

Values were in line with other case studies in riverine ecosystems, characterized by legacy contamination deriving from chlor-alkali plants. For example, concentrations between 0.050 and $0.076 \mathrm{mg} \mathrm{kg}^{-1} \mathrm{~d}$.w. are reported for the Savannah River (USA) [10]. At those levels, adverse effects on benthic invertebrates are not expected, according to the LOEC of $0.93 \mathrm{mg} \mathrm{kg}^{-1}$ d.w. reported for the benthic midge Chironomus riparius by Chibunda et al. [48]. In fact, benthic invertebrate communities show high diversity in this stretch of the Toce River, and they are only slightly influenced by sediment contamination, which may be bound also to the co-presence of other toxicants, such as DDT and its degradation products, and arsenic [29,32].

Similarly to what was observed in sediments, concentrations of $\mathrm{THg}$ in benthic invertebrates collected at Domo $\left(0.048 \pm 0.014 \mathrm{mg} \mathrm{kg}^{-1} \mathrm{~d}\right.$.w. $)$ were lower than those observed at Prata $\left(0.096 \pm 0.037 \mathrm{mg} \mathrm{kg}^{-1} \mathrm{~d} . \mathrm{w}.\right)$, which, in turn, were lower than values at the sites downstream of the factory $\left(0.126 \pm 0.037 \mathrm{mg} \mathrm{kg}^{-1} \mathrm{~d}\right.$.w.) (ANOVA, $\left.p<0.001\right)$ (Figure S1).

Concentrations were in line with those of invertebrates collected even in rivers not influenced by local active pollution sources. For example, Heptageniidae (range 
0.038-0.165 $\mathrm{mg} \mathrm{kg}^{-1}$ d.w.), Limnephilidae (0.038-0.165 $\mathrm{mg} \mathrm{kg}^{-1}$ d.w.) and Diptera (0.038-0.165 mg kg-1 d.w.) showed concentrations similar to those of the same taxa collected in two forested basins in US (range 0.05-0.212, 0.01-0.063 and 0.03-0.146 $\mathrm{mg} \mathrm{kg}^{-1} \mathrm{~d} . w$., respectively) [41]. On the contrary, Žižek et al. [49] reported values in River Idrijca (Slovenia), influenced by recent mercury mining activities, reaching concentrations of tens $\mathrm{mg} \mathrm{kg}^{-1} \mathrm{~d}$.w. for invertebrates. However, in the Toce, higher values downstream of the industrial area in comparison to the upstream sites prove the presence of a legacy contamination.

By comparing different taxa, all organisms showed similar values of $\mathrm{THg}$, except for Ephemeroptera Baetis, which accumulated significantly less than the other groups (Figure S2). At the sites downstream of the factory, differences between taxa were more marked, and Plecoptera Perla showed the highest values (Figure S2b).

Since the diet is considered the main exposure route to mercury for aquatic organisms, THg values in different FFGs were compared (Figure 2). THg concentrations for most taxa did not significantly change with the season ( $t$-test, $p>0.05)$, thus we supposed that FFG did not vary, and we could pool together data collected in different seasons. Similarly, Riva-Murray et al. [41] performed a stable isotope analysis in invertebrates of different US streams and found small variations between seasons. Our data showed THg values for grazers significantly lower than for the other groups (Figure 2). Gatherers-predators, shredders, and small-sized predators showed comparable values. At the downstream sites, large-sized predators showed concentrations significantly higher than those of the other FFGs, except for active filter feeders (Figure 2b). Similar results were obtained by Bates and Hall [18], who reported lower values for Gastropoda (grazers) in comparison to Dytiscidae/Notonectidae (predators) in US ponds. As expected, invertebrate FFGs generally show increasing amounts of THg with trophic levels [17,41].

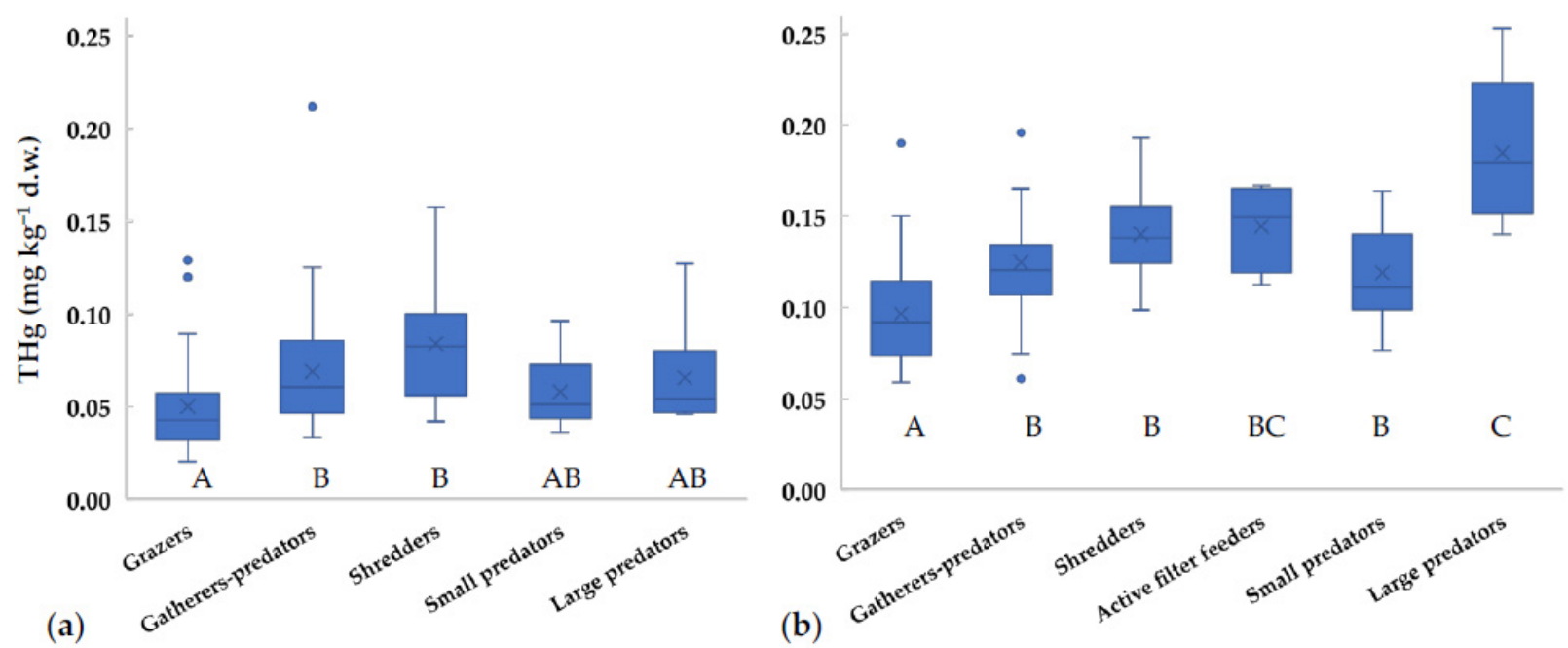

Figure 2. Concentrations of total mercury in different Functional Feeding Groups (FFGs) collected in the Toce River (a) upstream and (b) downstream of the industrial site between 2014 and 2018. $x=$ mean value, horizontal line in boxes $=$ median value, box $=25$ th -75 th percentiles, whiskers $=$ min-max range, points $=$ outliers. Uppercase letters represent significant differences between FFGs according to ANOVA test followed by Tukey post-hoc $(p<0.05)$.

Surprisingly, in the Toce River shredders showed concentrations in line with predators, while values are generally expected to be lower (e.g., [1,41]). However, this was observed also in other case studies, for example in the upper stream of the Francoli River (Spain), where Gammaridae (shredders) and Odonata (predators) showed similar values [50], as well as in Okefenokee Swamp (Georgia, USA) [51]. In fact, allochthonous inputs of terrestrial detritus and plant material may be an important mercury source to stream food webs [51,52]. A recent analysis of atmospheric mercury concentrations around the chloralkali plant shows that significant inputs are still deriving from the industrial area [53]. Thus, the mercury enrichment found in sediments at Prata, located upstream from the 
industrial plant, may derive from past and present contributions via atmospheric transport, even if the main wind direction is toward the river mouth.

\section{2. $\mathrm{MeHg}$ in Sediments and Biota}

$\mathrm{MeHg}$ in sediments was analyzed in samples collected in April 2017 and resulted below the LOD $\left(0.7 \mu \mathrm{g} \mathrm{kg}^{-1}\right)$, except for Bosco Tenso, where the concentration of $0.98 \mu \mathrm{g} \mathrm{kg}^{-1}$ d.w. accounted for $0.7 \%$ of THg. The highest value was found at Prata in 2013, where $\mathrm{MeHg}$ reached $3.8 \%$ ( $\mathrm{THg}=0.050 \mathrm{mg} \mathrm{kg}^{-1} \mathrm{~d}$.w.) [31]. These percent values are in line with other studies on riverine sediments. The Savanna River (Georgia, USA), characterized by a legacy contamination deriving from a chlor-alkali plant, presented percent $\mathrm{MeHg}$ in sediments comprised between $1.1 \%$ and $2.5 \%$ [10]. MeHg percentage in the estuary of Penobscot River (Maine, USA), also impacted by a chlor-alkali plant, was $2.9 \pm 0.3 \%$ [7]. Razavi et al. [54] reported for the Ontario River (Canada), downstream of a chlor-alkali plant, $\mathrm{MeHg}$ comprised between $0.02 \%$ and $0.6 \%$, even if concentrations were significantly higher than those of the Toce $\left(5 \mathrm{mg} \mathrm{kg}^{-1} \mathrm{~d}\right.$.w. for THg and $8.3 \mu \mathrm{g} \mathrm{kg}{ }^{-1} \mathrm{~d}$.w. for $\mathrm{MeHg}$, on average). $\mathrm{MeHg}$ concentrations in the Idrija River sediments (Slovenia), which long received mercury related to cinnabar ore extraction activity, represented $\leq 0.067 \%$ of $\mathrm{THg}$ (up to $727 \mathrm{mg} \mathrm{THg} \mathrm{kg}{ }^{-1}$ d.w.) [49] and similar percent MeHg values were reported close to the mouth of the Isonzo River (Northern Italy) (THg up to $7.53 \mathrm{mg} \mathrm{kg}^{-1} \mathrm{~d} . \mathrm{w}$.), which receives water from the Idrija River [55].

$\mathrm{MeHg}$ concentrations in benthic invertebrates collected in 2017 ranged between 3 and $88 \mu \mathrm{g} \mathrm{kg}^{-1} \mathrm{~d}$.w. and were correlated with THg in the organisms $(\mathrm{r}=0.75, p<0.05)$ and with THg in sediments $(\mathrm{r}=0.77, p<0.05)$. MeHg in tissues at sites upstream from the industrial area (mean of $16 \pm 12 \mu \mathrm{g} \mathrm{kg}{ }^{-1}$ d.w., $\mathrm{n}=9$ ) were significantly lower than concentrations in organisms collected downstream $\left(51 \pm 17 \mu \mathrm{g} \mathrm{kg}^{-1}\right.$ d.w., $\left.\mathrm{n}=15\right)(t$-test, $p<0.001)$. Besides, percent $\mathrm{MeHg}$ was lower in invertebrates collected upstream (21 $\pm 14 \%)$ in comparison to the downstream sites $(40 \pm 8 \%)(t$-test, $p<0.001)$. Higher mercury bioavailability and /or methylation in sediments at the latter sites may explain this result.

Regarding FFGs, MeHg concentrations in grazers were lower than in shredders (Figure 3a). On the contrary, percent $\mathrm{MeHg}$ showed similar values in all groups, with maxima up to $53 \%$ of $\mathrm{THg}$ (Figure $3 \mathrm{~b}$ ). Low $\mathrm{MeHg}$ percentages $(\leq 50 \%)$ were previously reported for grazing insects $[10,18,20]$, while median values around $55 \%$ were found for Trichoptera Limnephilidae (shredders) [20]. For omnivores and predators, $\mathrm{MeHg}$ generally represents most of THg, e.g., $>70 \%$ for Corixidae, Gerridae, Dytiscidae, Notonectidae, and crayfish $[10,18,20]$. In general, $\mathrm{MeHg}$ should increase with trophic level. This was observed by Mason et al. [17], who reported 20-40\% MeHg for herbivores/detritivores and $>70 \%$ for predators. Unfortunately, in our study the mass of large-size predators was not enough for $\mathrm{MeHg}$ analysis, thus a potential increase with trophic level could not be tested. However, this is not always observed in invertebrate communities, because the length of the trophic chain may be too low [41,56]. For example, Bates and Hall [18] found a $\delta^{15} \mathrm{~N}$ increase of $1.44-1.99 \%$ from grazers to predators, which accounts for less than a trophic level (a minimum of $2 \%$ is generally accepted between trophic levels, [20]). Another drawback is that it may be difficult to establish a common $\delta^{15} \mathrm{~N}$ baseline for different taxa. According to Diaz-Jaramillo et al. [56], MeHg at low trophic levels of benthic food webs can be better predicted by $\delta^{13} \mathrm{C}$ rather than $\delta^{15} \mathrm{~N}$ signatures, showing the importance of detritus cycle and biofilm as a primary $\mathrm{Hg}$ exposure pathway to macroinvertebrates. Unfortunately, we did not perform stable isotope analysis, and this limits the analysis of the trophic relations between taxa and food sources. 


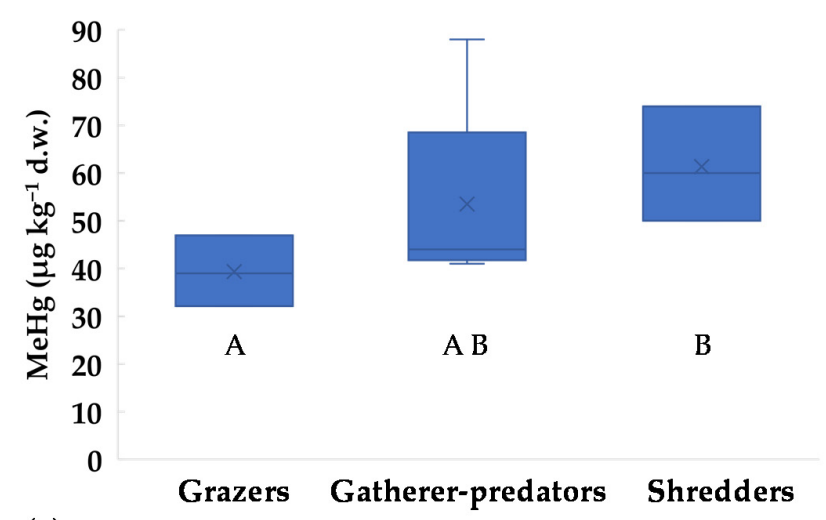

(a)

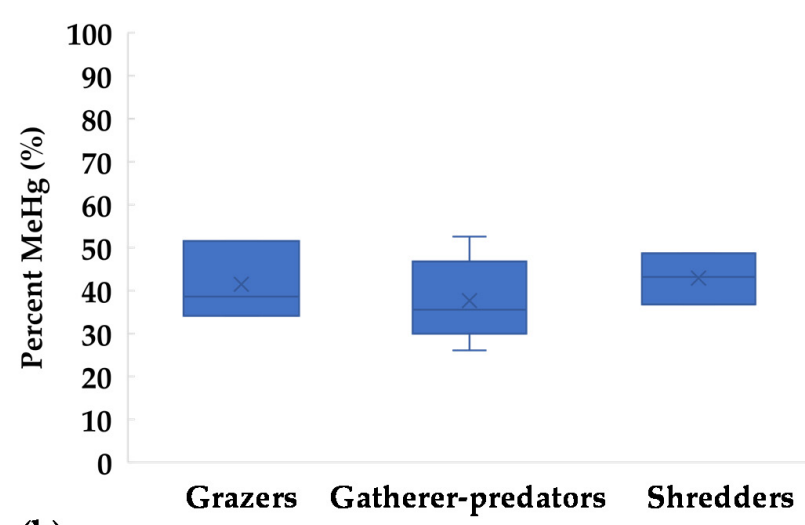

(b)

Figure 3. Concentrations of methylmercury in different Functional Feeding Groups (FFGs) collected in the Toce River downstream of the industrial site in 2017: (a) $\mathrm{MeHg}$ as $\mu \mathrm{g} \mathrm{kg}{ }^{-1} \mathrm{~d} . \mathrm{w}$. ; (b) $\mathrm{MeHg}$ as percent relative to $\mathrm{THg}$. $\mathrm{x}=$ mean value, horizontal line in boxes $=$ median value, box $=25$ th-75th percentiles, whiskers $=$ min-max range. Uppercase letters represent significant differences between FFGs according to Kruskall-Walis ANOVA test followed by Dunn's post-hoc $(p<0.05)$.

\subsection{Relation between BSAF and Environmental Variables}

Tissue concentrations of $\mathrm{THg}$ (and $\mathrm{MeHg}$ ) generally increased with increasing environmental concentrations, i.e., sediment $\mathrm{THg}$ concentrations, but the correlation coefficient between these variables was low $(r=0.23, p<0.05)$. Similar results were obtained even considering single taxa, as the highest coefficient $\mathrm{r}$ was $0.36(p<0.05)$, obtained for Heptageniidae, and it was even not significant for most taxa. The relation was weak even normalizing THg values in sediments to percent $\mathrm{OC}(\mathrm{r}=0.33, p<0.05$ considering all data). This confirms that $\mathrm{THg}$ concentration in sediments cannot be used directly as a predictor of an organism's accumulation [5,49]. This may be related primarily to geochemical factors and site-specific microbial activity, which affect mercury bioavailability and methylation rates. In rivers, only a small fraction of $\mathrm{THg}$ is generally bioavailable and it may change over time due to methylation/demethylation reactions, which are microbially mediated in sediments [4]. Thus, the local bioavailability of the metal is hardly predictable.

To evaluate bioavailability, the calculation of BSAF was carried out according to equation 1 for those taxa showing at least part of diet bound to sediments or particulate matter according to Table 1 (i.e., excluding the predators Rhyacophilidae and Perla). Values ranged between 0.2 and 4.6 (Figure S3). Mean values of each taxon were always above 1, showing efficient mercury bioaccumulation into living organisms (Figure S3) [12].

An inverse relation was found between BSAF and THg in sediments (Figure 4). This showed that the bioaccumulation capacity was higher at lower environmental concentrations. This relation was observed for mercury and for several metals in the dissolved phase $[21,23,57]$. The inverse relation is known also between metal dietary concentrations and trophic transfer $[8,19,57]$, while, to our knowledge, it is not reported in the literature for metal concentrations in sediments. This behavior has been related to the physiological regulation of uptake and excretion of metals, as well as to the storage and/or detoxification capacity of the organisms $[19,57]$. At low environmental concentrations, higher intake is observed for all metals, including mercury, since the uptake mechanisms for both essential and non-essential elements may follow similar routes [19]. At higher concentrations, internal regulation or saturation of ligand binding sites may occur, lowering the overall uptake rate of the contaminant [21].

It must be considered that in field studies the equilibrium between accumulation and exposure conditions may not be reached [23]. However, in our study, the inverse relation was observed for different taxa at different sites (Figure 4), reinforcing this finding. Notably, the inverse relation between $\mathrm{THg}$ concentrations in sediments or in the diet vs. mercury accumulated in the next highest trophic level may reduce concentration differences among sites and among trophic levels [19]. 

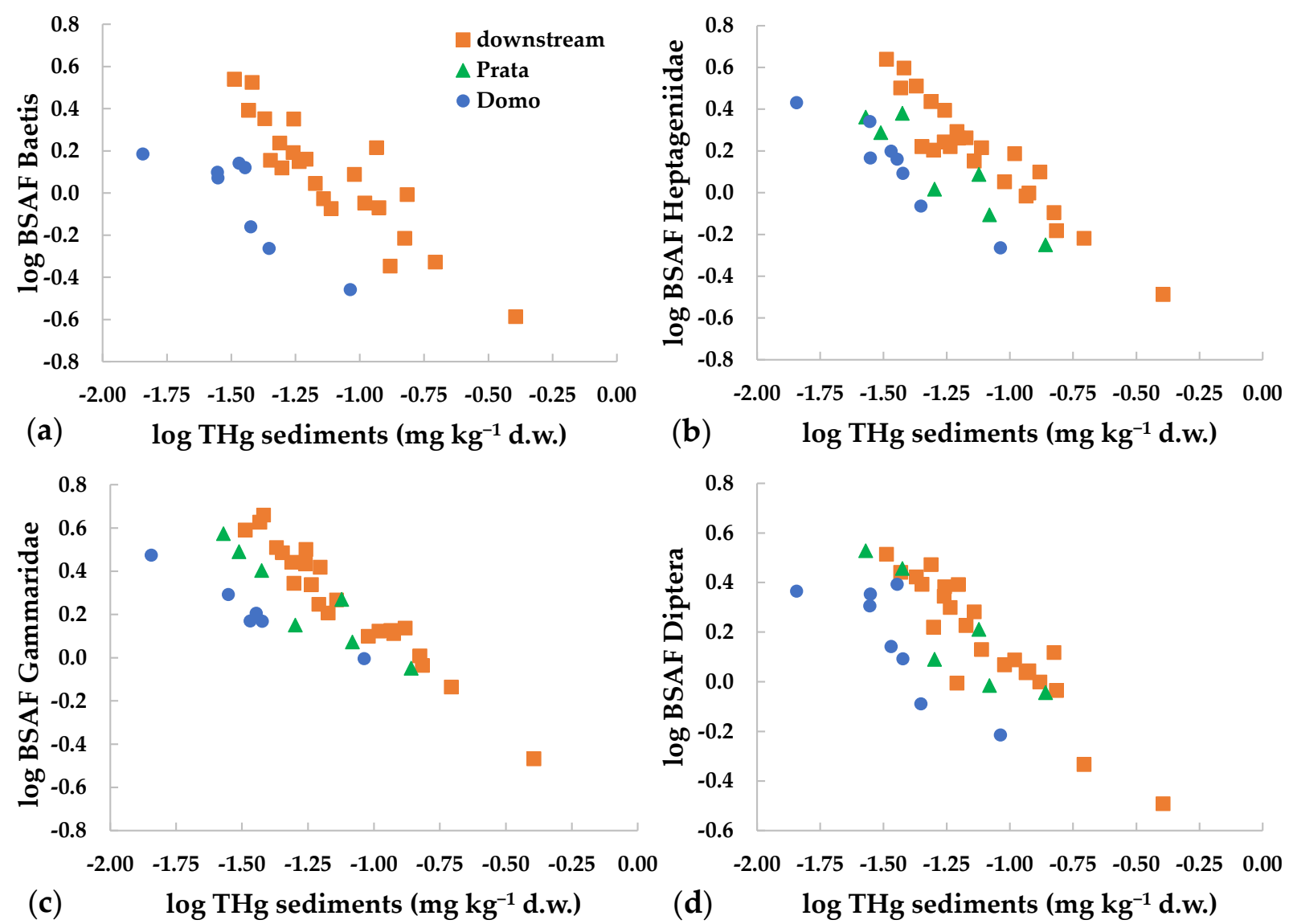

Figure 4. Relation between $\mathrm{THg}$ concentrations in sediments and BSAF values (log-transformed) for different invertebrate taxa collected at Domo, Prata and the three sites downstream of the industrial area (=downstream): (a) Baetis, (b) Heptageniidae, (c) Gammaridae, (d) Diptera.

Other environmental parameters may drive mercury bioavailability. For instance, OC may decrease the bioavailability of mercury, and the inverse relationship between BSAF and OC was already observed [12]. Here, as well, the correlation between these variables is significant, even if values are highly dispersed $(r=-0.46, p<0.05$, Figure S4a). On the contrary, relation with percent fine sediments was positive, even if weak $(\mathrm{r}=0.23, p<0.05$, Figure S4b).

Other chemical and physical parameters may influence mercury bioavailability at the water-sediment interface, such as oxygen levels [12], as well as microbial activity [4], which may be highly variable in rivers. Moreover, it must be considered that we analyzed only sediments as the dominant route for mercury exposure, while porewater and bottom water may be other important pathways. For example, Xu et al. [10] were able to connect labile mercury concentrations in porewater to bioaccumulation in biofilm and in the higher levels of riverine trophic chains.

Unfortunately, MeHg analysis in sediments was hampered by the low values, which were generally below the LOD of our instruments. Therefore, we could not establish a relation between bioaccumulation and $\mathrm{MeHg}$ exposure or other environmental variables. Even if $\mathrm{MeHg}$ is recognized as the most bioaccumulative species of mercury, due to high bioavailability and low excretion rates, the relation between tissue concentrations and exposure is not so straightforward, as for $\mathrm{THg}$, due to the complexity of physiological mechanisms which may drive accumulation and excretion, and in turn toxicity [21-23]. However, our data show that a significant part of mercury in the organism was in the organic form, raising the risk of biomagnification in the trophic chains. 


\subsection{Environmental Risk}

According to the European legislation, the EQS for mercury in biota is $20 \mu \mathrm{g} \mathrm{kg}$ w.w. of THg and applies to prey tissue with the aim to protect wildlife consumers of aquatic biota against secondary poisoning via the food chain [13,14]. The EQS was derived based on MeHg using the lowest available no observed effect concentration (NOEC) for birds and mammals and it is generally referred to fish, where the predominant form of mercury is $\mathrm{MeHg}$ (generally $>80 \%$ ) [13,14]. For comparison, by converting to wet weight mercury concentrations in invertebrates, values reached $73 \mu \mathrm{g} \mathrm{kg}^{-1}$ w.w. for $\mathrm{THg}$ and $17 \mu \mathrm{g} \mathrm{kg}{ }^{-1}$ w.w. for MeHg (Figure S5). By considering THg, the EQS was exceeded in $44 \%$ of samples. It was never exceeded at Domo, while downstream of the factory the mean value was always above or in line with the EQS. By considering $\mathrm{MeHg}$, the concentration of $20 \mu \mathrm{g} \mathrm{kg}^{-1}$ w.w. was almost reached by Heptageniidae and Gammaridae collected downstream.

Values of THg in invertebrates close to the EQS or even higher are frequently observed in freshwaters, even when point sources of contamination are not present [13,17,24]. Not surprisingly, values in insectivorous/omnivorous fish species collected in the Toce River [58,59] are one order of magnitude higher than the EQS (Figure S6). Many studies relate mercury concentrations in fish with their prey, such as benthic invertebrates $[2,10,12]$. The results obtained in the Toce River show how these organisms may actively transfer legacy contamination from sediments to higher trophic levels.

An interesting observation regarded the adult stages of some aquatic insects, which were captured during our surveys (Figure 5). Concentrations of THg in adults were generally in line with those measured in the corresponding larval stages ( $t$-test for dependent samples, $p>0.05)$, proving an efficient transfer of the contaminant from the aquatic environment to terrestrial trophic chains. Thus, it seems that metamorphosis does not imply significant excretion of mercury. This is also supported by the low values observed in exuviae in comparison to those of larvae and adults $(p<0.05)$ (Figure 5). Similar results were obtained in a lab experiment with the dipteran C. riparius exposed to the Toce River sediments, which showed similar body burdens in larvae and in imagos [26].

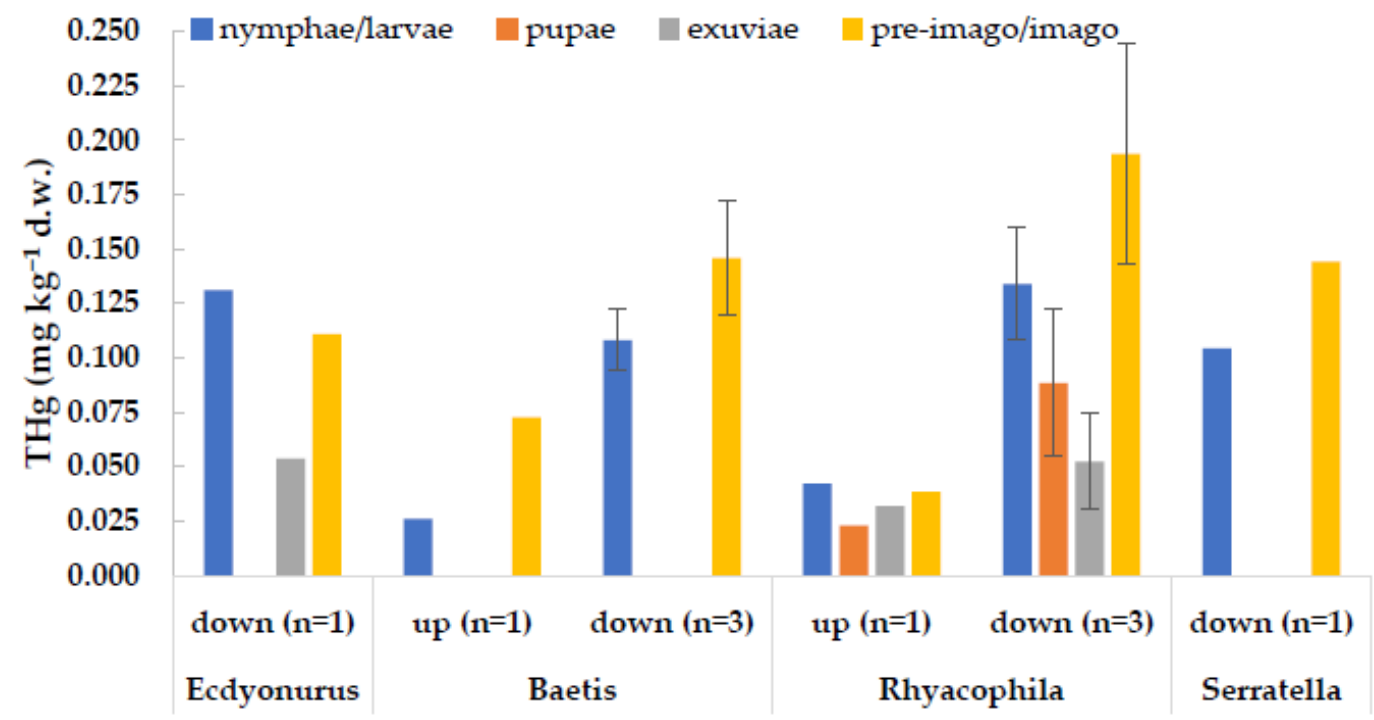

Figure 5. Concentrations of total mercury in different life stage of the same taxon, collected at the same site (up = upstream from the industrial area; down = downstream of the industrial area) and sampling date. Columns represent the mean value, bars are \pm 1 standard deviation. $\mathrm{n}=$ number of samples.

As well, Cid et al. [16] reported similar concentrations between nymphs and adults of the mayfly E. virgo collected in mercury-contaminated river sites, while values in moults were significantly lower. Gimbert et al. [22] proved for C. riparius that exoskeleton, gut 
content, and cellular debris account only for $10 \%$ of $\mathrm{Hg}$ accumulated by the organism, while the cytosolic fraction represents most of the body burden (90\%). This confirms that the main accumulation organ for mercury in freshwater insects is not the exoskeleton [21]. Similar concentrations of mercury in larvae and adults are reported also by Kraus et al. [25], as observed in case studies with low mercury concentrations. On the contrary, a higher fraction may be proportionally lost with metamorphosis when exposure concentrations increase [25], as reported by Rossaro et al. [60], who found in adults of C. riparius an average of $29 \%$ of $\mathrm{THg}$ concentration measured in larvae exposed to $5.5 \mu \mathrm{g} \mathrm{L}^{-1} \mathrm{HgCl}_{2}$ solutions.

We did not analyze MeHg in adults. However, according to Chételat et al. [24] $\mathrm{MeHg}: \mathrm{THg}$ ratio may even increase from larval to the adult stage: the authors reported $\mathrm{MeHg}$ concentrations 2.9 times higher in chironomid adults in comparison to larvae, representing the predominant form of mercury $(82 \pm 15 \%$ of $\mathrm{THg})$. These results underline how aquatic insects may play a key role in mercury transfer not only to aquatic but also to terrestrial trophic chains, where adults are prey for other insects, amphibians, birds, and mammals like bats [16].

\section{Conclusions}

The Toce River represents a case study characterized by legacy contamination, where mercury bioaccumulation is still of concern, notwithstanding the relatively low concentrations in sediments.

The analysis of mercury in biota is a direct method for assessing bioavailability. Benthic invertebrates represent all categories of consumers, from herbivorous to secondary predators, giving the opportunity to analyze different exposure pathways and highlighting $\mathrm{THg}$ and $\mathrm{MeHg}$ concentrations at the base of aquatic and terrestrial food webs.

As expected, mercury values proved to increase from prey to predators, reaching concentrations above the EQS and thus potentially toxic to top predators. Results are consistent with previous studies, showing that mercury can cause secondary poisoning to wildlife at environmental concentrations not toxic to prey. The high persistence of the contaminant across insect metamorphosis, associated with low effects on larval and adult survival (as proved by the species-rich invertebrate communities of the Toce), may determine consistent flux and cycling in the environment.

Mercury concentrations, organic carbon, and the presence of fine-grained fractions proved to be significant variables determining bioaccumulation from sediments. However, other potential exposure routes, i.e., through porewater and bottom water, need to be investigated. Moreover, analysis of stable isotopes is necessary to improve knowledge on the trophic relations between different taxa and food sources.

Supplementary Materials: The following are available online at https:/ /www.mdpi.com/article/ 10.3390/toxics9090197/s1, Figure S1: Concentrations of total mercury in sediments and in different taxa of benthic organisms collected in the Toce River, Figure S2: THg concentrations in different taxa collected in the Toce River upstream and downstream of the chlor-alkali plant between 2014 and 2018, Figure S3: BSAF values in different Functional Feeding Groups, Figure S4: Correlation between BSAF values and OC concentrations or percent fine sediments, Figure S5: Comparison of THg and $\mathrm{MeHg}$ concentrations (w.w.) in benthic invertebrates with the European EQS for biota, Figure S6: $\mathrm{THg}$ and $\mathrm{MeHg}$ concentrations in benthic invertebrates and fish collected in the Toce River.

Author Contributions: L.M.: conceptualization, investigation, formal analysis, writing. C.R.: investigation, data curation. L.V.: investigation, data curation. All authors have read and agreed to the published version of the manuscript.

Funding: This research was partially funded by the International Commission for the Protection of Italian-Swiss Waters (CIPAIS), Research Programs 2013-2015, 2016-2018 and 2019-2021 www.cipais. org (accessed on 19 May 2021).

Institutional Review Board Statement: Not applicable.

Informed Consent Statement: Not applicable. 
Data Availability Statement: Data are available in the reports of the International Commission for the Protection of Italian-Swiss Waters (CIPAIS) regarding hazardous substances in Lake Maggiore (years 2014-2019), which are published and downloadable at www.cipais.org (accessed on 19 May 2021).

Acknowledgments: We wish to thank Pietro Volta (CNR-IRSA Pallanza, VB, Italy) for fish sampling and preparation, Clara Zanini for field and lab work with benthic invertebrates, and Bruno Rossaro (University of Milan, Milan, Italy) for helpful suggestions on data analysis.

Conflicts of Interest: The authors declare no conflict of interest.

\section{References}

1. Tsui, M.T.K.; Finlay, J.C.; Nater, E.A. Mercury Bioaccumulation in a Stream Network. Environ. Sci. Technol. 2009, 43, 7016-7022. [CrossRef] [PubMed]

2. Ward, D.M.; Nislow, K.H.; Folt, C.L. Bioaccumulation Syndrome: Identifying Factors That Make Some Stream Food Webs Prone to Elevated Mercury Bioaccumulation: Bioaccumulation Syndrome. Ann. N. Y. Acad. Sci. 2010, 1195, 62-83. [CrossRef] [PubMed]

3. Amos, H.M.; Jacob, D.J.; Kocman, D.; Horowitz, H.M.; Zhang, Y.; Dutkiewicz, S.; Horvat, M.; Corbitt, E.S.; Krabbenhoft, D.P.; Sunderland, E.M. Global Biogeochemical Implications of Mercury Discharges from Rivers and Sediment Burial. Environ. Sci. Technol. 2014, 48, 9514-9522. [CrossRef] [PubMed]

4. Cossa, D.; Garnier, C.; Buscail, R.; Elbaz-Poulichet, F.; Mikac, N.; Patel-Sorrentino, N.; Tessier, E.; Rigaud, S.; Lenoble, V.; Gobeil, C. A Michaelis-Menten Type Equation for Describing Methylmercury Dependence on Inorganic Mercury in Aquatic Sediments. Biogeochemistry 2014, 119, 35-43. [CrossRef]

5. Bigham, G.N.; Murray, K.J.; Masue-Slowey, Y.; Henry, E.A. Biogeochemical Controls on Methylmercury in Soils and Sediments: Implications for Site Management: Geochemical Controls on Mercury Methylation. Integr. Environ. Assess. Manag. 2017, 13, 249-263. [CrossRef]

6. Ullrich, S.M.; Tanton, T.W.; Abdrashitova, S.A. Mercury in the Aquatic Environment: A Review of Factors Affecting Methylation. Crit. Rev. Environ. Sci. Technol. 2001, 31, 241-293. [CrossRef]

7. Amirbahman, A.; Massey, D.I.; Lotufo, G.; Steenhaut, N.; Brown, L.E.; Biedenbach, J.M.; Magar, V.S. Assessment of Mercury Bioavailability to Benthic Macroinvertebrates Using Diffusive Gradients in Thin Films (DGT). Environ. Sci. Process. Impacts 2013, 15, 2104-2114. [CrossRef]

8. Lavoie, R.A.; Jardine, T.D.; Chumchal, M.M.; Kidd, K.A.; Campbell, L.M. Biomagnification of Mercury in Aquatic Food Webs: A Worldwide Meta-Analysis. Environ. Sci. Technol. 2013, 47, 13385-13394. [CrossRef]

9. Coelho, J.P.; Mieiro, C.L.; Pereira, E.; Duarte, A.C.; Pardal, M.A. Mercury Biomagnification in a Contaminated Estuary Food Web: Effects of Age and Trophic Position Using Stable Isotope Analyses. Mar. Pollut. Bull. 2013, 69, 110-115. [CrossRef]

10. Xu, X.; Bryan, A.L.; Mills, G.L.; Korotasz, A.M. Mercury Speciation, Bioavailability, and Biomagnification in Contaminated Streams on the Savannah River Site (SC, USA). Sci. Total Environ. 2019, 668, 261-270. [CrossRef]

11. Rennie, M.; Collins, N.; Purchase, C.F.; Tremblay, A. Predictive Models of Benthic Invertebrate Methylmercury in Ontario and Quebec Lakes. Can. J. Fish. Aquat. Sci. 2005, 62, 2770-2783. [CrossRef]

12. Taylor, D.L.; Linehan, J.C.; Murray, D.W.; Prell, W.L. Indicators of Sediment and Biotic Mercury Contamination in a Southern New England Estuary. Mar. Pollut. Bull. 2012, 64, 807-819. [CrossRef]

13. Lepom, P.; Irmer, U.; Wellmitz, J. Mercury Levels and Trends (1993-2009) in Bream (Abramis Brama L.) and Zebra Mussels (Dreissena Polymorpha) from German Surface Waters. Chemosphere 2012, 86, 202-211. [CrossRef] [PubMed]

14. Nguetseng, R.; Fliedner, A.; Knopf, B.; Lebreton, B.; Quack, M.; Rüdel, H. Retrospective Monitoring of Mercury in Fish from Selected European Freshwater and Estuary Sites. Chemosphere 2015, 134, 427-434. [CrossRef] [PubMed]

15. European Environment Agency. European Waters: Assessment of Status and Pressures 2018; Publications Office: Luxembourg, 2018.

16. Cid, N.; Ibáñez, C.; Palanques, A.; Prat, N. Patterns of Metal Bioaccumulation in Two Filter-Feeding Macroinvertebrates: Exposure Distribution, Inter-Species Differences and Variability across Developmental Stages. Sci. Total Environ. 2010, 408, 2795-2806. [CrossRef] [PubMed]

17. Mason, R.P.; Laporte, J.-M.; Andres, S. Factors Controlling the Bioaccumulation of Mercury, Methylmercury, Arsenic, Selenium, and Cadmium by Freshwater Invertebrates and Fish. Arch. Environ. Contam. Toxicol. 2000, 38, 283-297. [CrossRef] [PubMed]

18. Bates, L.M.; Hall, B.D. Concentrations of Methylmercury in Invertebrates from Wetlands of the Prairie Pothole Region of North America. Environ. Pollut. 2012, 160, 153-160. [CrossRef]

19. Jardine, T.D.; Kidd, K.A.; O' Driscoll, N. Food Web Analysis Reveals Effects of PH on Mercury Bioaccumulation at Multiple Trophic Levels in Streams. Aquat. Toxicol. 2013, 132-133, 46-52. [CrossRef]

20. Edmonds, S.T.; O’Driscoll, N.J.; Hillier, N.K.; Atwood, J.L.; Evers, D.C. Factors Regulating the Bioavailability of Methylmercury to Breeding Rusty Blackbirds in Northeastern Wetlands. Environ. Pollut. 2012, 171, 148-154. [CrossRef]

21. Tsui, M.T.K.; Wang, W.-X. Uptake and Elimination Routes of Inorganic Mercury and Methylmercury in Daphnia Magna. Environ. Sci. Technol. 2004, 38, 808-816. [CrossRef]

22. Gimbert, F.; Geffard, A.; Guédron, S.; Dominik, J.; Ferrari, B.J.D. Mercury Tissue Residue Approach in Chironomus riparius: Involvement of Toxicokinetics and Comparison of Subcellular Fractionation Methods. Aquat. Toxicol. 2016, 171, 1-8. [CrossRef] 
23. McGeer, J.C.; Brix, K.V.; Skeaff, J.M.; DeForest, D.K.; Brigham, S.I.; Adams, W.J.; Green, A. Inverse Relationship between Bioconcentration Factor and Exposure Concentration for Metals: Implications for Hazard Assessment of Metals in the Aquatic Environment. Environ. Toxicol. Chem. 2003, 22, 1017-1037. [CrossRef] [PubMed]

24. Chételat, J.; Amyot, M.; Cloutier, L.; Poulain, A. Metamorphosis in Chironomids, More than Mercury Supply, Controls Methylmercury Transfer to Fish in High Arctic Lakes. Environ. Sci. Technol. 2008, 42, 9110-9115. [CrossRef] [PubMed]

25. Kraus, J.M.; Walters, D.M.; Wesner, J.S.; Stricker, C.A.; Schmidt, T.S.; Zuellig, R.E. Metamorphosis Alters Contaminants and Chemical Tracers in Insects: Implications for Food Webs. Environ. Sci. Technol. 2014, 48, 10957-10965. [CrossRef] [PubMed]

26. Marziali, L.; Valsecchi, L. Mercury Bioavailability in Fluvial Sediments Estimated Using Chironomus riparius and Diffusive Gradients in Thin-Films (DGT). Environments 2021, 8, 7. [CrossRef]

27. Guilizzoni, P.; Levine, S.N.; Manca, M.; Marchetto, A.; Lami, A.; Ambrosetti, W.; Brauer, A.; Gerli, S.; Carrara, E.A.; Rolla, A.; et al. Ecological Effects of Multiple Stressors on a Deep Lake (Lago Maggiore, Italy) Integrating Neo and Palaeolimnological Approaches. J. Limnol. 2012, 71, 1. [CrossRef]

28. Guzzella, L.M.; Novati, S.; Casatta, N.; Roscioli, C.; Valsecchi, L.; Binelli, A.; Parolini, M.; Solcà, N.; Bettinetti, R.; Manca, M.; et al Spatial and Temporal Trends of Target Organic and Inorganic Micropollutants in Lake Maggiore and Lake Lugano (Italian-Swiss Water Bodies): Contamination in Sediments and Biota. Hydrobiologia 2018, 824, 271-290. [CrossRef]

29. Marziali, L.; Guzzella, L.; Salerno, F.; Marchetto, A.; Valsecchi, L.; Tasselli, S.; Roscioli, C.; Schiavon, A. Twenty-Year Sediment Contamination Trends in Some Tributaries of Lake Maggiore (Northern Italy): Relation with Anthropogenic Factors. Environ. Sci. Pollut. Res. 2021, 28, 38193-38208. [CrossRef]

30. MacDonald, D.D.; Ingersoll, C.G.; Berger, T.A. Development and Evaluation of Consensus-Based Sediment Quality Guidelines for Freshwater Ecosystems. Arch. Environ. Contam. Toxicol. 2000, 39, 20-31. [CrossRef]

31. Pisanello, F.; Marziali, L.; Rosignoli, F.; Poma, G.; Roscioli, C.; Pozzoni, F.; Guzzella, L. In Situ Bioavailability of DDT and Hg in Sediments of the Toce River (Lake Maggiore Basin, Northern Italy): Accumulation in Benthic Invertebrates and Passive Samplers. Environ. Sci. Pollut. Res. 2016, 23, 10542-10555. [CrossRef]

32. Marziali, L.; Rosignoli, F.; Drago, A.; Pascariello, S.; Valsecchi, L.; Rossaro, B.; Guzzella, L. Toxicity Risk Assessment of Mercury, DDT and Arsenic Legacy Pollution in Sediments: A Triad Approach under Low Concentration Conditions. Sci. Total Environ. 2017, 593-594, 809-821. [CrossRef] [PubMed]

33. Belfiore, C. Efemerotteri (Ephemeroptera). In Guide Per Il Riconoscimento Delle Specie Animali Delle Acque Interne Italiane; Consiglio Nazionale Delle Ricerche (CNR): Rome, Italy, 1983; Volume 24.

34. Rivosecchi, L. Ditteri (Diptera). In Guide Per Il Riconoscimento Delle Specie Animali Delle Acque Interne Italiane; Consiglio Nazionale Delle Ricerche (CNR): Rome, Italy, 1984; Volume 28.

35. Campaioli, S.; Ghetti, P.F.; Minelli, A.; Ruffo, S. Manuale per Il Riconoscimento Dei Macroinvertebrati Delle Acque Dolci Italiane; Provincia Autonoma di Trento: Trento, Italy, 1994; Volume 1.

36. Campaioli, S.; Ghetti, P.F.; Minelli, A.; Ruffo, S. Manuale per Il Riconoscimento Dei Macroinvertebrati Delle Acque Dolci Italiane; Provincia Autonoma di Trento: Trento, Italy, 1999; Volume 2, ISBN 88-7702-089-X.

37. Vane, C.H.; Kim, A.W.; Emmings, J.F.; Turner, G.H.; Moss-Hayes, V.; Lort, J.A.; Williams, P.J. Grain Size and Organic Carbon Controls Polyaromatic Hydrocarbons (PAH), Mercury (Hg) and Toxicity of Surface Sediments in the River Conwy Estuary, Wales, UK. Mar. Pollut. Bull. 2020, 158, 111412. [CrossRef]

38. Kersten, M.; Smedes, F. Normalization Procedures for Sediment Contaminants in Spatial and Temporal Trend Monitoring. J. Environ. Monitor. 2002, 4, 109-115. [CrossRef] [PubMed]

39. Scherer, C.; Brennholt, N.; Reifferscheid, G.; Wagner, M. Feeding Type and Development Drive the Ingestion of Microplastics by Freshwater Invertebrates. Sci. Rep. 2017, 7, 17006. [CrossRef]

40. Schmidt-Kloiber, A.; Hering, D. Www.freshwaterecology.info-An Online Tool That Unifies, Standardises and Codifies More than 20,000 European Freshwater Organisms and Their Ecological Preferences. Ecol. Indic. 2015, 53, 271-282. Available online: https:/ / www.freshwaterecology.info/ (accessed on 3 May 2021). [CrossRef]

41. Riva-Murray, K.; Chasar, L.C.; Bradley, P.M.; Burns, D.A.; Brigham, M.E.; Smith, M.J.; Abrahamsen, T.A. Spatial Patterns of Mercury in Macroinvertebrates and Fishes from Streams of Two Contrasting Forested Landscapes in the Eastern United States. Ecotoxicology 2011, 20, 1530-1542. [CrossRef]

42. US-EPA. Method 7473-Mercury in Solids and Solutions by Thermal Decomposition, Amalgamation, and Atomic Absorption Spectrophotometry. Revision 0; US Environmental Protection Agency: Washington, DC, USA, 1998.

43. US-EPA. Methods for the Determination of Total Organic Carbon (TOC) in Soils and Sediments; US Environmental Protection Agency, Ecological Risk Assessment Support Center, Office of Research and Development NCEA-C-1282, EMASC-001: Washington, DC, USA, 2002.

44. De Vos, B.; Lettens, S.; Muys, B.; Deckers, J.A. Walkley-Black Analysis of Forest Soil Organic Carbon: Recovery, Limitations and Uncertainty. Soil Use Manag. 2007, 23, 221-229. [CrossRef]

45. Jones, H.J.; Swadling, K.M.; Butler, E.C.V.; Macleod, C.K. Complex Patterns in Fish-Sediment Mercury Concentrations in a Contaminated Estuary: The Influence of Selenium Co-Contamination? Estuar. Coast. Shelf Sci. 2014, 137, 14-22. [CrossRef]

46. Hammer, Ø.; Harper, D.A.T.; Ryan, P.D. PAST: Paleontological Statistics Software Package for Education and Data Analysis. Palaeontol. Electron. 2001, 4, 9. 
47. Xue, W.; Kwon, S.Y.; Grasby, S.E.; Sunderland, E.M.; Pan, X.; Sun, R.; Zhou, T.; Yan, H.; Yin, R. Anthropogenic Influences on Mercury in Chinese Soil and Sediment Revealed by Relationships with Total Organic Carbon. Environ. Pollut. 2019, $255,113186$. [CrossRef] [PubMed]

48. Chibunda, R.T. Chronic Toxicity of Mercury $\left(\mathrm{HgCl}_{2}\right)$ to the Benthic Midge Chironomus riparius. Int. J. Environ. Res. 2009, 3, 455-462. [CrossRef]

49. Žižek, S.; Horvat, M.; Gibičar, D.; Fajon, V.; Toman, M.J. Bioaccumulation of Mercury in Benthic Communities of a River Ecosystem Affected by Mercury Mining. Sci. Total Environ. 2007, 377, 407-415. [CrossRef]

50. Roig, N.; Sierra, J.; Ortiz, J.D.; Merseburger, G.; Schuhmacher, M.; Domingo, J.L.; Nadal, M. Integrated Study of Metal Behavior in Mediterranean Stream Ecosystems: A Case-Study. J. Hazard. Mater. 2013, 263, 122-130. [CrossRef]

51. George, B.M.; Batzer, D. Spatial and Temporal Variations of Mercury Levels in Okefenokee Invertebrates: Southeast Georgia. Environ. Pollut. 2008, 152, 484-490. [CrossRef] [PubMed]

52. St. Louis, V.L.; Rudd, J.W.M.; Kelly, C.A.; Hall, B.D.; Rolfhus, K.R.; Scott, K.J.; Lindberg, S.E.; Dong, W. Importance of the Forest Canopy to Fluxes of Methyl Mercury and Total Mercury to Boreal Ecosystems. Environ. Sci. Technol. 2001, 35, 3089-3098. [CrossRef] [PubMed]

53. Fantozzi, L.; Guerrieri, N.; Manca, G.; Orrù, A.; Marziali, L. An Integrated Investigation of Atmospheric Gaseous Elemental Mercury Transport and Dispersion Around a Chlor-Alkali Plant in the Ossola Valley (Italian Central Alps). Toxics $2021,9,172$. [CrossRef] [PubMed]

54. Razavi, N.R.; Ridal, J.J.; de Wit, W.; Hickey, M.B.C.; Campbell, L.M.; Hodson, P.V. Ebullition Rates and Mercury Concentrations in St. Lawrence River Sediments and a Benthic Invertebrate. Environ. Toxicol. Chem. 2013, 32, 857-865. [CrossRef]

55. Covelli, S.; Faganeli, J.; Horvat, M.; Brambati, A. Mercury Contamination of Coastal Sediments as the Result of Long-Term Cinnabar Mining Activity (Gulf of Trieste, Northern Adriatic Sea). Appl. Geochem. 2001, 16, 541-558. [CrossRef]

56. Díaz-Jaramillo, M.; Muñoz, C.; Rudolph, I.; Servos, M.; Barra, R. Seasonal Mercury Concentrations and $\Delta 15 \mathrm{~N}$ and $\Delta 13 \mathrm{C}$ Values of Benthic Macroinvertebrates and Sediments from a Historically Polluted Estuary in South Central Chile. Sci. Total Environ. 2013, 442, 198-206. [CrossRef]

57. DeForest, D.K.; Brix, K.V.; Adams, W.J. Assessing Metal Bioaccumulation in Aquatic Environments: The Inverse Relationship between Bioaccumulation Factors, Trophic Transfer Factors and Exposure Concentration. Aquat. Toxicol. 2007, 84, 236-246. [CrossRef]

58. International Commission for the Protection of the Italian-Swiss Waters (CIPAIS). Indagini Sulle Sostanze Pericolose Nell'ecosistema Del Lago Maggiore. Programma 2016-2018. Rapporto Annuale 2017; CIPAIS: Verbania, Italy, 2018; Available online: http:/ / www. cipais.org/ (accessed on 19 May 2021).

59. International Commission for the Protection of the Italian-Swiss Waters (CIPAIS). Indagini Sulle Sostanze Pericolose Nell'ecosistema Del Lago Maggiore. Programma 2019-2021. Rapporto Annuale 2019; CIPAIS: Verbania, Italy, 2020; Available online: http:/ / www. cipais.org/ (accessed on 19 May 2021).

60. Rossaro, B.; Gaggino, G.F.; Marchetti, F. Accumulation of Mercury in Larvae and Adults, Chironomus riparius (Meigen). Bull. Environ. Contam. Toxicol. 1986, 37, 402-406. [CrossRef] [PubMed] 